\title{
Hybrid fuel cell-based energy system with metal hydride hydrogen storage for small mobile applications
}

\author{
G.L. Guizzi ${ }^{\mathrm{a}}$, M. Manno ${ }^{\mathrm{a}}$, M. De Falco ${ }^{\mathrm{b}, \mathrm{c}}$ \\ aUniversità di Roma “Tor Vergata”, Dipartimento di Ingegneria dell'Impresa \\ Via del Politecnico, 1 - 00133 Rome - Italy \\ guizzi@ing.uniroma2.it, michele.manno@uniroma2.it, \\ ${ }^{b}$ Università di Roma “La Sapienza”, Dipartimento di Ingegneria Chimica \\ Materiali Ambiente \\ Via Eudossiana 18 - 00184 Rome, Italy \\ ${ }^{c}$ Labor s.r.l., Via G. Peroni, 386 - 00131 Rome - Italy \\ m.defalco@labor-roma.it
}

\begin{abstract}
This paper describes the general architecture of a hybrid energy system, whose main components are a proton exchange membrane fuel cell, a battery pack and an ultracapacitor pack as power sources, and metal hydride canisters as energy storage devices, suitable to supply power to small mobile non-automotive devices in a flexible and variable way.

The first experimental results carried out on a system prototype are described, showing that the extra components, required in order to manage the hybrid system, do not remarkably affect the overall system efficiency, which is always higher than $36 \%$ in all the test configurations examined. In fact, the system allows the fuel cell to work most often at quasi-optimal conditions, near its maximum
\end{abstract}

\footnotetext{
* Corresponding author
} 
efficiency (i.e. at low/medium loads), because high external loads are met by the combined effort of the fuel cell and the ultracapacitors. For the same reason, the metal hydride storage system can be used also under highly dynamic operating conditions, notwithstanding its usually poor kinetic performance.

\section{Keywords}

Hybrid system; Fuel Cell; Ultracapacitor; Metal hydride

\section{Nomenclature}

\begin{tabular}{|c|c|}
\hline$a$ & activity \\
\hline$A_{a}$ & active area $/ \mathrm{cm}^{2}$ \\
\hline$E$ & energy / J \\
\hline$F$ & Faraday's constant / $\mathrm{C} \mathrm{mol}^{-1}$ \\
\hline$g$ & molar Gibbs free energy / J mol ${ }^{-1}$ \\
\hline$h$ & molar enthalpy / J mol ${ }^{-1}$ \\
\hline$i$ & current density / $\mathrm{A} \mathrm{cm}^{-2}$ \\
\hline$i_{0}$ & exchange current $/ \mathrm{A} \mathrm{cm}^{-2}$ \\
\hline$I$ & current / A \\
\hline$m$ & mass / kg \\
\hline$m$ & coefficient in the eq. expressing the polarization curve / V \\
\hline$n$ & coefficient in the eq. expressing the polarization curve $/ \mathrm{A}^{-1} \mathrm{~cm}^{2}$ \\
\hline$n_{e}$ & number of moles of electrons transferred per mole of fuel \\
\hline$\dot{n}$ & hydrogen flow rate / $\mathrm{mol} \mathrm{s}^{-1}$ \\
\hline$N$ & number of cells \\
\hline$P$ & power / kW \\
\hline$r$ & area-specific resistance / $\Omega \mathrm{cm}^{2}$ \\
\hline
\end{tabular}




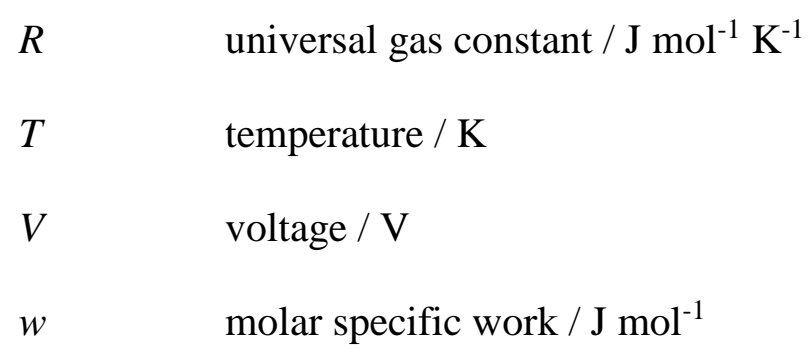

Greek symbols

$\alpha \quad$ coefficient in the eq. expressing the polarization curve

$\varepsilon \quad$ specific energy / $\mathrm{Wh} \mathrm{kg}^{-1}$

$\eta \quad$ efficiency

$\mu_{f} \quad$ fuel utilization coefficient

$\pi \quad$ specific power $/ \mathrm{W} \mathrm{kg}^{-1}$

$\tau \quad$ power generator autonomy / $\mathrm{h}$

\section{Subscripts}

aux auxiliaries

e electrons

$f \quad$ formation

FC fuel cell

$T \quad$ tank; storage system

\section{Introduction}

FEMAG (Flexible Ecological Multipurpose Advanced Generator) is a CRAFT project financed within the $6^{\text {th }}$ EU Framework Programme, coordinated by the Italian company Labor s.r.l., started on September 2004 and completed on June 2007.

Its aim was to explore the optimized integration of components and power aggregates, delivering a hybrid power generator, based on the integration of a PEMFC with ultracapacitors and a battery pack, for the flexible supply at variable 
power of small non-automotive devices, in the $125-1000 \mathrm{~W}$ power range. The energy storage within the system was to be carried out by means of metal hydride tanks due to their intrinsic safety features, which made them of great value for this type of application.

This hybrid architecture makes the FEMAG prototype quite useful for those applications where the average energy consumption is low, but peak loads can briefly occur. In this situation, the hybrid architecture, its most prominent components being the fuel cell and the ultracapacitors for power generation and the metal hydride canisters for energy storage, offer several advantages over traditional energy systems:

- the fuel cell can work at low/medium load where its efficiency is higher;

- the fuel cell can be designed according to the average power demand, thus saving in terms of cost, weight and footprint;

- the fuel cell can be operated without excessively fast load variations, thus reducing its wear and effectively making its life longer;

- the ultracapacitor pack can release high amounts of energy in a very short time, thus making it possible to meet peak loads much higher than the fuel cell's rated power;

- the ultracapacitors can be recharged without significant energy losses, thus making the hybrid system operation highly efficient;

- the adoption of the fuel cell as the main generator implies that the output from all the energy sources is of the same type, i.e. electric power, resulting in a simplified system design;

- the metal hydride storage system offers significant advantages in terms of safety features if compared to conventional compressed hydrogen tanks; 
- the hybrid architecture overcomes one of the main drawbacks of metal hydride storage systems, i.e. their poor performance under highly dynamic loads, since the ultracapacitors respond to rapid transients while the fuel cell operates under "mild" dynamic loads.

Hybrid systems are indeed receiving great consideration thanks to their usefulness in applications that are subject to highly variable external loads [1-5].

The FEMAG prototypes developed are based on the integration of commercial and pre-commercial devices and components. The aggregated FEMAG generator design is based on the criterion of minimizing the fuel cell's rated power, handing over to the battery pack and, especially, to the ultracapacitors the task of supplying power during transients and peak-load phases. As a result, the fuel cell's life can be expected to increase, as well as the overall system efficiency. The project's goal was to develop two prototype power systems, namely an electric wheelchair for disabled people and an industrial AGV (Automated Guided Vehicle) for the transportation of finished goods inside an industrial area. The hybrid structure of the FEMAG power unit is especially helpful in these applications, due to their wide load variability and, above all, to the possibility of very high loads occurring for short periods (for instance, to go over a sloping path with the wheelchair, or to lift a heavy load with the AGV).

A similar concept has been recently deployed also by Hydrogenics Corporation in a lift truck powered by a hybrid system composed of fuel cell, ultracapacitors and batteries [6]. The main difference with the FEMAG project is that compressed hydrogen storage tanks are used to store hydrogen onboard, instead of metal hydride canisters (see section 2.1.1). Hydrogenics' lift truck has been successfully tested in Canadian GM and FedEx plants. 


\section{Description of the FEMAG project}

\subsection{FEMAG prototypes}

The main outcome of the FEMAG project was expected to be the assembly of two prototypes integrating the FEMAG advanced hybrid generator architecture. In particular, these prototypes should demonstrate the ability of the power system to cope with different kind of loads; to that end, two demonstration systems were built, targeting different applications:

1. a wheelchair for disabled people (low-end prototype, shown in Fig. 1);

2. an Automated Guided Vehicle (AGV) for the transportation of finished goods inside an industrial area (high-end prototype).

Of these two systems, the first has been completely developed: an existing electric wheelchair has been obtained, and its battery pack and power management unit replaced with a "low-end" FEMAG generator, so that an actual FEMAG wheelchair is available for testing in LABOR s.r.l. laboratories (Figs. 1 and 2). On the other hand, the AGV prototype has not been actually built, due to its more demanding size and driving range, but a "high-end" FEMAG generator has been assembled in laboratory and subjected to the same type of load profiles that are usually encountered in the normal operation of an AGV.

Both prototypes share the same architecture, based on the FEMAG generator concept (Fig. 3), albeit with different components due to their different size and load requirements. More specifically, the physical components implemented are:

1. one PEM fuel cell;

2. metal hydride tanks for on-board hydrogen storage;

3. an ultracapacitor pack;

4. a battery pack; 


\section{5. two electronic DC/DC converters;}

6. one electronic controller for efficient power management.

In the FEMAG concept the battery pack is supposed to be able to cope with some steady loads temporarily exceeding the nominal or instant power of the fuel cell, or to supply peak loads together with the ultracapacitors. However, in the actual prototypes the battery pack is dimensioned so as to provide only the necessary power for start-up operations, storing only a little amount of energy (as compared to the overall amount stored in the prototype), even though the battery pack is still managed according to the FEMAG concept's specifications (it can directly respond to the load, and it is recharged by the fuel cell), so that it can be converted into a useful range extender as soon as its size is suitably increased. The downgrading of the battery pack therefore greatly helps in reducing system's size and weight, without compromising its effectiveness.

\subsubsection{Hydrogen storage}

Overall, metal hydride hydrogen storage, even though at present unsuitable for transport applications mainly due to its excessive weight, can still represent an interesting option for those mobile applications that are currently powered by batteries, thanks to their safety features and remarkably high energy density. In order to make a comparison, for modern Li-ion batteries the specific energy and the energy density can be estimated as, respectively, $125 \mathrm{Wh} \mathrm{kg}^{-1}$ and $210 \mathrm{Wh}$ $1^{-1}[7-10]$.

In the case of metal hydride tanks coupled to fuel cells, both the specific energy and, more remarkably, the energy density can reach higher values. According to a survey of data collected from many leading manufacturers and suppliers [11], the gravimetric density of metal hydride canisters is around $1.2 \%$, and therefore the 
specific energy of the storage system is approximately $\varepsilon=400 \mathrm{Wh} \mathrm{kg}^{-1}$ (based on hydrogen LHV, $120 \mathrm{MJ} \mathrm{kg}^{-1}$ ). The useful specific energy can be obtained from this value by first reducing it according to the overall efficiency of the system $\eta$, and then again taking into consideration the fuel cell's own mass. In other words, if $m_{T} \eta \varepsilon$ is the useful energy stored in the system ( $\varepsilon$ being the chemical energy stored per unit mass of the storage system, $\eta$ the overall efficiency), and $m_{F C} \pi$ is the rated power of the fuel cell ( $\pi$ is the specific power of the fuel cell), the relationship between these two quantities is given by what can be defined as the power generator autonomy $\tau$, so that $m_{F C} \pi \tau=m_{T} \eta \varepsilon$. The specific energy of the system made up of the tank and the fuel cell can thus be evaluated as

$$
\varepsilon_{\text {system }}=\frac{E}{m_{\text {system }}}=\frac{m_{T} \eta \varepsilon}{m_{T}+m_{F C}}=\frac{\eta \varepsilon}{1+m_{F C} / m_{T}}=\frac{\eta \varepsilon}{1+\eta \varepsilon / \pi \tau}
$$

The power generator's autonomy clearly depends on the particular applications considered, being, as a rule, longer for backup systems and shorter for portable devices. For the FEMAG target applications it is possible to take into consideration as an average value $\tau=2 \mathrm{~h}$ (the practical autonomy is of course longer because $\tau$ refers to a constant operating conditions at maximum power), while the overall system efficiency can be estimated as approximately $\eta=40 \%$. As for the specific power of PEM fuel cells, automotive PEM fuel cells' stacks can reach specific powers as high as $1200 \mathrm{~W} \mathrm{~kg}^{-1}[12,13]$, but the stand-alone fuel cell, including all necessary auxiliary components (such as air management system, ECU, etc.), has obviously a quite lower specific power: a reference value that can be taken into consideration is $\pi=320 \mathrm{~W} \mathrm{~kg}^{-1}$ [13], which is also approximately valid for the fuel cell of the high-end FEMAG prototype (section 2.3). 
Under these assumptions, one obtains a final value of $\varepsilon_{\text {system }}=130 \mathrm{Wh} \mathrm{kg}^{-1}$, which, even though it should only be considered as a rough estimate, is at least equal than what can be achieved with the best Li-ion battery technology; however, the performance of the fuel cell system is even more remarkable in terms of energy density.

The hydrogen density in metal hydride storage systems is approximately $100 \mathrm{~g} \mathrm{l}^{-1}$ [14], resulting in an energy density of about $3500 \mathrm{Wh}^{-1}$, so that, taking into account the overall system efficiency, the useful energy density results $1400 \mathrm{Wh}^{-1}[11]$.

The fuel cell stack's power density can be estimated as $1750 \mathrm{~W} \mathrm{l}^{-1}$ for recent automotive high-power applications [12], so that it is reasonable to assume that the power density of low-power fuel cells can be at least $800 \mathrm{~W} \mathrm{1}^{-1}$; under the further assumption that only half the total volume is occupied by the FC stack, the overall fuel cell's power density can be estimated as $400 \mathrm{~W} \mathrm{1}^{-1}$. Following the same line of reasoning as in the case of the specific power evaluation, the ratio between the volume of the storage system and the volume taken up by the fuel cell can therefore be estimated as $1400 \mathrm{Wh} \mathrm{l}^{-1} /\left(400 \mathrm{~W}^{-1} \times 2 \mathrm{~h}\right)=1.75$. Therefore, the overall energy density is $1400 \mathrm{Wh}^{-1} / 2.75 \cong 500 \mathrm{Wh}^{-1}$, a figure considerably higher than what can be reached with Li-ion batteries.

As a matter of fact, the actual figures reached for the two prototypes developed in the FEMAG project are somewhat lower. For the low-end application, taking also into account the ultracapacitor pack, total mass and volume of the system are approximately $13.9 \mathrm{~kg}$ and $4.8 \mathrm{l}$. Since the energy stored is $3 \mathrm{kWh}$, with the assumption $\eta=0.4$, the specific energy results $85 \mathrm{Wh} \mathrm{kg}^{-1}$, and the energy density is $250 \mathrm{Wh}^{-1}$. For the high-end application, total mass and volume are 
approximately $36 \mathrm{~kg}$ and $24 \mathrm{l}$, while the energy stored is $6 \mathrm{kWh}$. Therefore, in this case the specific energy is $67 \mathrm{Wh} \mathrm{kg}^{-1}$, and the energy density is $100 \mathrm{Wh}^{-1}$ These rather poor results can be explained taking into account that the components are not optimized in order to improve their specific energy and energy density. This is particularly true for the metal hydride canisters of the highend application, that are designed so as to comply with severe regulations for pressure vessels (see section 2.3), resulting in a system heavier than what would have been necessary for a low-pressure canister; furthermore, inside the canister there is also an internal heat exchanger that allows to improve its kinetic performance but also drastically increase its footprint. Taking into account that the fuel cell does not operate under highly dynamic conditions, thanks to the hybrid architecture, the internal heat exchanger could be eliminated, even though this would considerably lengthen the recharge process.

Several mobile applications have indeed been developed substituting conventional batteries with a fuel cell powered by metal hydride cartridges; among them a professional video-camera application developed by Jadoo Power Systems, Inc. is particularly noteworthy $[9,15]$.

\subsection{FEMAG architecture}

The blocks presented in Fig. 3 are to be considered as logical and functional blocks, each one performing one specific function; they can correspond in practice to sub-circuits of a main control board, or be developed as individual items. This representation allows to identify and discuss easily the operational modes of the system.

It can be noticed that a power bus collects power from the different sources and conveys it to the load, via a DC/DC converter (indicated as SR4) whose task is to 
control that the variable input DC voltage is converted to the nearly constant voltage level required by the load.

The three possible sources of power are connected in parallel to the power bus. The ultracapacitor pack is placed directly on the bus without any controlling device; this is possible thanks to its particular characteristics of very low internal resistance, which makes its behavior clearly different than the fuel cell's and the battery pack's; the ultracapacitors are also inherently ready to deliver significant power peaks, and it is not necessary to introduce a device to control their behavior in recharge and discharge.

A controller (named SR2 in figure) is located between the power bus and the fuel cell, with a twofold task: to avoid that excessive currents flow through the fuel cell and to manage the priority of intervention of the fuel cell towards the load; a very similar task is performed by the controller named SR3 with respect to the battery pack. Another controller, named SR1, in conjunction with the switches S1 and S2, establishes the conditions of charge and discharge for the battery pack, depending also on the instantaneous power availability in the fuel cell's output. More in detail, the converters and switches of the FEMAG architecture have the tasks described in the following paragraphs.

\subsubsection{Controller SR1}

This block represents a switching regulator that checks if the fuel cell is supplying less than its rated power and directs the available power to the battery pack for recharging. The control feedback is provided by the difference between the current supplied by the fuel cell and the current flowing to the load; this also involves implicitly that the ultracapacitor pack, since it is located close to the 
load, is recharged with priority with respect to the battery pack, and that it is seen by the SR1, SR2 and SR3 converters as part of the load itself.

\subsubsection{Controller SR2}

This block represents a switching regulator, which manages the priority of intervention of the fuel cell in supplying the load. The output power from this block is regulated according to the power bus voltage level, thus making the fuel cell run at full power (if needed) until a threshold voltage level is reached, so as to recharge the ultracapacitor pack (whose state of charge depends on its voltage). Therefore, the threshold voltage level acts as an indicator of the ultracapacitor pack's state of charge. When the threshold is reached, the converter allows the fuel cell to gradually decrease its power output.

\subsubsection{Controller SR3}

This block represents a switching regulator similar to SR2, performing an analogous task for the benefit of the battery pack. It allows that a maximum amount of power is extracted from the batteries, power rate being a critical parameter in the operation of batteries that should be controlled in order to avoid a drastic reduction of their lifetime. The controller keeps the output DC voltage constant until a maximum power is reached, beyond which it starts reducing the output voltage in order to reduce the priority of intervention on the load; the voltage is reduced progressively, keeping the power supplied by the batteries at a given maximum value. 


\subsubsection{Controller SR4}

This is the main DC/DC converter, directly interfaced with the load: it operates so as to keep the output voltage consistent with the requirements of the load, at the varying conditions of input DC voltage and current.

\subsubsection{Switch S1}

The switch S1 is enabled when the battery pack needs recharging and surplus power is available from the fuel cell; it operates together with the switch S2 to allow battery recharging and discharging operations.

\subsubsection{Switch S2}

The switch S2 connects alternatively the batteries to the load or to the fuel cell, depending on the state of charge of the battery.

\subsection{FEMAG components}

An extensive market search was carried out in order to identify the optimal components for the two different FEMAG prototypes (high-end and low-end). The main components selected for the high-end prototype, which was subjected to the tests described in section 3.3, are now briefly presented.

The high-end prototype has been equipped with a fuel cell manufactured by the Swiss company MES-DEA sa. The DEA 1.5 fuel cell, still a prototype product, is composed of a fuel cell stack, a feeding air blower and a cooling air blower, managed by an ECU. The main technical specifications are:

- $\quad$ rated (max.) power $1.5 \mathrm{~kW}$

- DC voltage output $36-57 \mathrm{~V}$

- 60 cells

- $\quad$ active area $A_{a} 61 \mathrm{~cm}^{2}$ 
- $\quad$ overall weight $7 \mathrm{~kg}$

The ultracapacitors for the high-end prototype were chosen from the BOOTSCAP $^{\circledR}$ series (model BPAK0052 P015) produced by the American company Maxwell Technologies.

Size and weight of each ultracapacitor are:

- volume: 0.5661

- length: $216 \mathrm{~mm}$

- $\quad$ width: $69 \mathrm{~mm}$

- $\quad$ height: $38 \mathrm{~mm}$

- $\quad$ mass: $500 \mathrm{~g}$

Its main technical features are:

- rated voltage: $15 \mathrm{~V}$

- capacitance: $52 \mathrm{~F}$

- $\quad$ energy stored $\left(1 / 2 \mathrm{CV}^{2} / \mathrm{m}\right): 3.25 \mathrm{Wh} \mathrm{kg}^{-1}$

In order to reach the output voltage required for this application $(90 \mathrm{~V}$ on the power bus), 6 ultracapacitors have been connected in series. The resulting capacitance is therefore $8.67 \mathrm{~F}$.

Finally, the hydrogen-storage tanks were purchased from the Austrian company Treibacher AG. In particular, the FEMAG prototype for the AGV is equipped with 2 MHS-1000IHE tanks, where the number 1000 designate the nominal capacity in standard liters, and the acronym "IHE" specifies that the tank contains an internal heat exchanger for fast recharging operations, using cold water in order to limit the temperature increase of the metal hydride during the absorption process, so as to obtain good kinetics for the hydriding reaction.

The main characteristics of the MHS-1000IHE unit are:

- nominal capacity: $1 \mathrm{Nm}^{3}$ 
- $\quad$ storage alloy: AUERSTORE ${ }^{\odot}$, a patented AB2-type alloy containing Fe, $\mathrm{Mn}, \mathrm{Ti}, \mathrm{V}, \mathrm{Zr}$

- $\quad$ approx. dimensions (LxD): $500 \mathrm{~mm}$ x $115 \mathrm{~mm}$

- $\quad$ tank weight: $13 \mathrm{~kg}$

- max pressure: 100 bar

- max pressure for charging: $30 \mathrm{bar}$

- working temperature: up to $65^{\circ} \mathrm{C}$

- $\quad$ vessel material: stainless steel

- equilibrium pressure: $~ 5$ bar @ $25^{\circ} \mathrm{C}, \sim 13$ bar @ $40{ }^{\circ} \mathrm{C}$ (mid-plateau)

It is worth to observe that the MHS1000IHE storage unit is a pressure vessel manufactured, tested and certified according to TPED ("Transportable Pressure Equipment Directive”) 99/36/EC.

\section{Experimental results}

In the present paragraph, the experimental results obtained on the high-end

FEMAG prototype power generator are presented and discussed.

\subsection{Fuel cell performance}

In order to assess the overall performance of the system, it was first necessary to identify the performance of the fuel cell, where the conversion of the fuel's chemical energy to electric energy takes place, together with the most relevant energy losses.

The DEA1.5 fuel cell described in section 2.3 is basically composed of a stack of 60 cells, an air blower for feeding oxidant (air) to the fuel cell, and a cooling air blower. 
The fuel cell performance has been evaluated by means of an electronically controlled variable electric load; stack voltage and current, as well as load voltage and current, have been measured at different load conditions.

Figure 4 shows the cell voltage $V_{1}=V / N$ (i.e. the "polarization curve") as a function of the current density $i=I / A_{a}$, while stack voltage and power output are shown as functions of stack current in Fig. 5.

One common analytical expression that can be used to model the polarization curve of a fuel cell is [16]:

$$
V_{1}=E-\frac{R T}{\alpha n_{e} F} \log \left(\frac{i}{i_{0}}\right)-r i-m \exp (n i)
$$

where $n_{e}=2$ for the pure hydrogen reaction considered in this application, and

$$
F=96485.34 \mathrm{C} \mathrm{mol}^{-1} \text {. }
$$

The reversible cell potential $E$ is given by the Nernst equation:

$$
E=E^{0}+\frac{R T}{n_{e} F} \log \left(\frac{a_{\mathrm{H}_{2}} a_{\mathrm{O}_{2}}^{\frac{1}{2}}}{a_{\mathrm{H}_{2} \mathrm{O}}}\right)=1.1734 \mathrm{~V}
$$

where the operating temperature is $60{ }^{\circ} \mathrm{C}$, the oxygen activity is 0.21 since air is used as oxidant, and finally $E^{0}$ is the theoretical cell voltage at standard temperature and pressure:

$$
E^{0}=\frac{-\Delta_{f} g^{0}}{n_{e} F}=1.1846 \mathrm{~V}
$$

where $\Delta_{f} g^{0}=-228.6 \mathrm{~kJ} \mathrm{~mol}^{-1}$ is the change in molar Gibbs free energy of formation at standard pressure and temperature.

The experimental points obtained allowed to find the empirical coefficients of eq. (2), reported in Table 1, by means of a non-linear fitting technique. 
The efficiency of the energy conversion process can be evaluated by means of the following expressions:

$\eta_{\text {stack }}=\mu_{f} \frac{n_{e} F V_{1}}{-\Delta_{f} h^{0}}$

where $\Delta_{f} h^{0}=-241.8 \mathrm{~kJ} \mathrm{~mol}^{-1}$ is the change in molar enthalpy of formation at standard temperature and pressure, and $\mu_{f}$ is the fuel utilization coefficient defined by the following expression:

$\mu_{f}=\frac{N I}{n_{e} F \dot{n}}$

In the case at hand, the fuel cell intermittently purges excess hydrogen to the atmosphere, so that fuel utilization coefficient is lower than 1. Lacking direct experimental data about the hydrogen flow rate, a good estimate for a PEM fuel cell such as the one here considered is $\mu_{f}=95 \%$ [17], neglecting the variation of the fuel utilization coefficient with the current density, which becomes important only at low loads $[18,19]$

The current drawn by the auxiliaries (ECU and air blowers) has been evaluated as the difference between stack current and net current output (Fig. 6), and the following analytical expression of its correlation with the net current output has been found by fitting the experimental data:

$I_{a u x}=I_{a u x}^{*}+\frac{\operatorname{sgn}\left(I_{n e t}-I_{n e t}^{*}\right)+1}{2} \cdot a \cdot\left(I_{n e t}-I_{n e t}^{*}\right)$

with $I_{\text {aux }}^{*}=0.88 \mathrm{~A}, I_{\text {net }}^{*}=10.59 \mathrm{~A}$ and $a=0.07463$. Therefore the current $I_{\text {aux }}$ is constant at low loads, while it increases proportionally to the net current output at medium and high loads.

The power consumption due to the auxiliaries can then be estimated as: 


$$
P_{\text {aux }}=V_{\text {stack }} I_{\text {aux }}
$$

so that the corresponding fraction of energy lost can be taken into account by means of the following parameter:

$$
\eta_{\text {aux }}=1-\frac{P_{\text {aux }}}{P_{\text {stack }}}=1-\frac{I_{\text {aux }}}{I_{\text {stack }}}
$$

since the power supplied by the stack is:

$$
P_{\text {stack }}=V_{\text {stack }} I_{\text {stack }}
$$

The net power output is further diminished by ohmic losses, which determine a voltage drop between the fuel cell and the load, but this energy loss is not to be ascribed to the fuel cell.

Finally, the overall fuel cell efficiency, reported in Fig. 7 along with the stack efficiency, is given by:

$\eta_{F C}=\eta_{\text {stack }} \eta_{a u x}$

The overall efficiency exhibits a maximum at low-medium loads, because at low loads the relative importance of the power required by the auxiliaries increases, while at high loads the energy conversion efficiency decreases due to higher energy losses inside the stack.

\subsection{Experimental test conditions}

The prototype was subject to variable load profiles, with a test cycle obtained by repeating a certain number of times (in this case, 5 times) a base cycle composed of a rapid increase from no load to a peak power of $1.5 \mathrm{~kW}$, followed by a high power level maintained for a specific time. After a rest period, the load was again suddenly increased to the peak power, and then maintained at a low power level (Fig. 8). 
The software specifically designed for these experiments allowed to freely set the following parameters:

- frequency of the base cycle repetition;

- number of base cycles to be executed;

- $\quad$ high power level;

- low power level;

- $\quad$ permanent duration, i.e. how long the load was maintained at the high and low power level;

- transient duration, i.e. the time interval between the beginning of the load increase up to peak power and the beginning of the high or low power level permanence.

Figure 8 describes the base load cycle and highlights the abovementioned parameters.

The experimental tests were carried out with combinations arising form the following values of the parameters:

- $\quad$ base cycle frequency: 500 hour $^{-1}$;

- number of base cycles to be executed: 5 ;

- $\quad$ high power level: 800/900/1000 W;

- low power level: 300/400/500 W;

- $\quad$ permanent duration: $5 / 10 / 15 / 20 / 25 / 30 \mathrm{~s}$;

- transient duration: $1 / 2 \mathrm{~s}$.

The FEMAG control panel is shown in Fig. 9, where it is possible to identify the most important power flows and the main components of the prototype. The figure also indicates the points where voltage, current and power were measured and recorded, as functions of time, by the data acquisition system during the experimental tests carried out on the prototype. 
More specifically, the available data at the end of each test were:

- $\quad$ voltage, current and power at the inlet of the first DC/DC converter (designated as SR2 in the general FEMAG architecture, Fig. 3): $V_{i n, 1}$, $I_{i n, 1}, P_{i n, 1}$

- voltage, current and power at the outlet of the first DC/DC converter (SR2): $V_{\text {out }, 1}, I_{\text {out }, 1}, P_{\text {out }, 1}$;

- power at the inlet of the second DC/DC converter (designated as SR4 in Fig. 3): $P_{i n, 2}$;

- $\quad$ voltage, current and power at the load (i.e. at the outlet of the SR4 converter): $V_{\text {load }}, I_{\text {load }}, P_{\text {load }}$;

- $\quad$ hydrogen pressure.

Based on these measured variables, it was also possible to estimate all the other relevant variables, according to the following procedure:

- the current drawn by the fuel cell's auxiliaries $I_{\text {aux }}$ according to eq. (7);

- the stack current $I_{\text {stack }}$ as the sum of $I_{\text {in, } 1}$ and $I_{\text {aux }}$, and consequently the current density $i=I_{\text {stack }} / A_{a}$;

- $\quad$ the single-cell voltage $V_{1}$ according to the polarization curve, eq. (2);

- the stack voltage $V_{\text {stack }}$;

- $\quad$ the stack power output $P_{\text {stack }}$, eq. (10);

- the power consumption due to the FC auxiliaries $P_{a u x}$, eq. (8);

- the instantaneous FC stack and overall efficiencies $\eta_{\text {stack }}$ and $\eta_{F C}$, eqs. (5) and (11).

As a matter of fact, for the cyclical load imposed on the prototype (Fig. 8), in order to assess the overall system efficiency it is more useful to consider the energy use over a number of cycles rather than the instantaneous power. Thus, the total energy consumed by the external load can be defined as: 


$$
E_{\text {load }}=\int P_{\text {load }} d t
$$

and, since the instantaneous chemical power consumption can be calculated as:

$$
P_{\text {fuel }}=\frac{P_{\text {stack }}}{\eta_{\text {stack }}}
$$

the primary energy consumption can thus be evaluated as:

$$
E_{\text {fuel }}=\int P_{\text {fuel }} d t
$$

The overall efficiency of the system can finally be evaluated as:

$$
\eta=\frac{E_{\text {load }}}{E_{\text {fuel }}}
$$

\subsection{Test results}

The FEMAG system response to the load cycle previously illustrated is described in this paragraph.

In particular, detailed data about the system performance will be discussed with reference to the following load cycle:

- $\quad$ high power level: $1000 \mathrm{~W}$

- low power level: $500 \mathrm{~W}$

- transient duration: $1 \mathrm{~s}$

- $\quad$ permanent duration: $20 \mathrm{~s}$;

The average power output resulting from these parameters is $447.9 \mathrm{~W}$.

Before introducing the test results, it is important to observe that all the data acquisition that will be presented have been smoothed with the moving average method (spanning 51 elements) in order to eliminate as much as possible the background noise from the signal: that is why in the following figures the power peaks may seem not to reach the required maximum level of $1.5 \mathrm{~kW}$. 
Figure 10 (top) shows the power vs. time pattern recorded at the electric load $\left(P_{\text {load }}\right)$ and at the SR2 converter inlet $\left(P_{i n, 1}\right)$, as well as the estimation of the stack power $\left(P_{\text {stack }}\right)$ based on the calculations illustrated in the previous paragraph. It is possible to observe that the FEMAG prototype could easily meet the highly dynamic load imposed, while the fuel cell was actually subject to a much smoother load, thanks to the electronic controller's management strategy, which required the intervention of the ultracapacitors.

Figure 10 (bottom), on the other hand, shows the power time-patterns at the SR2 converter outlet $\left(P_{\text {out }, 1}\right)$, at the ultracapacitor pack outlet $\left(P_{s c}\right)$ and at the SR4 converter inlet $\left(P_{i n, 2}\right)$. Negative power levels for the variable $P_{s c}$ occur when the electronic controller make the fuel cell recharge the ultracapacitor pack.

From the comparison between $P_{i n, 2}$ and $P_{\text {load }}$ it is possible to determine the SR4 converter efficiency as lower than $90.0 \%$. Much higher efficiency is reached by the SR2 converter, which connects the fuel cell to the ultracapacitor bus: the ratio between $P_{o u t, 1}$ and $P_{i n, 1}$ is, on average, $97.4 \%$.

Figure 11 (top) shows the current time-patterns at the load, at the fuel cell stack and at the SR2 converter inlet. The same considerations as for Fig. 10 can be made. Figure 11 (bottom), on the other hand, shows the currents circulating on the ultracapacitor bus: $I_{o u t, 1}$ is the current leaving the SR2 converter, $I_{s c}$ is the current leaving the ultracapacitor pack (a negative value is observed when the current actually flows into the ultracapacitor pack), and finally $I_{i n, 2}$ is the current flowing into the SR4 converter.

Figure 12 describes the most significant voltage levels in the system. The stack voltage is determined analytically by means of the procedure described in the previous paragraph. The voltage drop between the stack voltage $V_{\text {stack }}$ and the voltage at the SR2 converter inlet $\left(V_{i n, 1}\right)$ is most probably due to simple ohmic 
losses in the cables connecting the fuel cell to the SR2 converter: the voltage drop is indeed found to be proportional to the current circulating in those cables, i.e.

$$
I_{i n, 1} \text {. }
$$

Performing the efficiency calculation suggested at the end of the previous paragraph, eq. (15), the overall system efficiency for this configuration can be estimated as:

$$
\eta=\frac{\int P_{\text {load }} d t}{\int P_{\text {fuel }} d t} \cong 37.8 \%
$$

which is a quite satisfactory result: the implementation of the complete FEMAG system determines only a slight penalty on the overall efficiency if compared to the efficiency of the fuel cell directly interfaced to the load via a DC/DC converter similar to SR4 (whose efficiency is, as mentioned above, approximately 90\%). On the other hand, the FEMAG system makes it possible to satisfy a much wider load range than it would have been possible with the fuel cell alone; furthermore, the fuel cell is "shielded" from possible harmful effects of rapid transients and also from power peaks exceeding its rated power, and finally under these "mild" dynamic operating conditions the metal hydride storage system is able to deliver the hydrogen flux required by the fuel cell, notwithstanding its poor dynamic performance.

An estimation of the efficiencies of the different components of the FEMAG system subjected to the abovementioned load cycle can be performed as follows:

$$
\begin{gathered}
\eta_{F C}=\frac{\int P_{\text {net }} d t}{\int P_{\text {fuel }} d t} \cong 46.1 \% \\
\eta_{\text {cables }}=\frac{\int P_{i n, 1} d t}{\int P_{n e t} d t} \cong 97.4 \%
\end{gathered}
$$




$$
\begin{aligned}
& \eta_{S R 2}=\frac{\int P_{\text {out }, 1} d t}{\int P_{\text {in }, 1} d t} \cong 97.4 \% \\
& \eta_{S R 4}=\frac{\int P_{\text {load }} d t}{\int P_{\text {in }, 2} d t}=\frac{\int P_{\text {load }} d t}{\int P_{\text {out }, 1} d t} \cong 86.1 \%
\end{aligned}
$$

The efficiency $\eta_{\text {cables }}$ refers to the (small) ohmic losses in the cables connecting the fuel cell to the SR2 converter (the resistance of the cables has been evaluated as approximately $50 \mathrm{~m} \Omega$ ).

It is worth noting the very good performance of the converter SR2 (which was designed specifically for this application), especially if compared to the SR4 converter, which was on the contrary commercially acquired.

It should be noted that the net energy released (or absorbed) by the ultracapacitor pack during the cyclical operation here considered is practically nil, because of the high efficiency of the recharging operation, of the short length of the cables involved, and finally because at the end of each cycle the ultracapacitors' initial state of charge is restored. Under these assumptions, $\int P_{s c} d t=0$, so that $\int P_{i n, 2} d t=\int P_{\text {out }, 1} d t$, from which follows eq. (20).

It is also interesting to split the energy losses due to the fuel cell between those due to the conversion process taking place inside the stack, and those caused by the power consumption of the fuel cell's auxiliaries:

$$
\begin{gathered}
\eta_{\text {stack }}=\frac{\int P_{\text {stack }} d t}{\int P_{\text {fuel }} d t} \cong 50.6 \% \\
\eta_{\text {aux }}=\frac{\int P_{\text {net }} d t}{\int P_{\text {stack }} d t} \cong 91.0 \%
\end{gathered}
$$

It is very important to observe that, thanks to the FEMAG prototype architecture, the fuel cell was able to work under quasi-optimal conditions, as it is confirmed 
by its overall efficiency, eq. (17); this would not happen if the fuel cell were directly subject to the external load. Therefore, the efficiency penalty introduced by the more complex architecture of the prototype can be compensated by the possibility to work under better conditions from the efficiency point of view. Table 2 gives the calculated overall efficiencies for 15 different working conditions. It is possible to see that the efficiency is never lower than $36 \%$, and that it is higher at lower loads, as it could be easily foreseen.

Figure 13 shows the energy fluxes (in the case discussed above of $1000 \mathrm{~W}$ high power level, $500 \mathrm{~W}$ low power level and $20 \mathrm{~s}$ permanent duration) for the overall cyclical operation described in Figs. 10-12. The recharging of the ultracapacitor pack is deemed to impose practically negligible energy losses, as previously mentioned. Most of the energy available in the fuel is lost because of the energy conversion process in the fuel cell; it is also possible to observe that the converter SR2, specifically engineered for the FEMAG project, reach a remarkable efficiency.

The power fluxes at two particular time instants are shown in Fig. 14 and Fig. 15. The first one describes the situation at time $90 \mathrm{~s}$, when the ultracapacitor pack is releasing power along with the fuel cell in order to meet the external load (the fuel cell at this time is not able to meet alone the external load, because the rate of increase of its power output is controlled by the FEMAG architecture); in the second figure, on the other hand, the power fluxes at the time instant $110 \mathrm{~s}$ is illustrated, when almost no external load is applied to the FEMAG system and thus the fuel cell is able to recharge the ultracapacitor pack. 


\section{Conclusions}

This work describes the general architecture and illustrates the experimental tests carried out on the high-end FEMAG prototype, reporting the most important results obtained.

The FEMAG architecture is based on a hybrid power train, whose power generating components are one fuel cell and one ultracapacitor pack (possibly assisted by a battery pack), controlled by an electronic control unit (ECU), which is able to draw the power required by the external load from the most convenient source at a given time: if the external load is subject to a sudden peak, then the ECU activates the ultracapacitors, which will be later recharged by the fuel cell. This configuration makes it possible to select the fuel cell based on the average load typical of a given application, and not on its maximum power requirement, thus saving in terms of size, weight and overall cost; moreover, the resulting fuel cell operating conditions are such that the metal hydride storage system, whose dynamic performance is usually rather poor, is always able to supply the required hydrogen flux, because it is the ultracapacitor pack that responds to the most rapid transients.

The extra components, required in order to manage the hybrid system, do not remarkably affect the overall system efficiency, which is always higher than $36 \%$ in all the test configurations examined. As a matter of fact, the fuel cell is most often able to work at quasi-optimal conditions, near its maximum efficiency (i.e. at low/medium loads), because high external loads (that would impose a penalty on the fuel cell efficiency, should the fuel cell work alone) are met by the combined effort of the fuel cell and the ultracapacitors.

It is very important to observe that, even if the whole FEMAG system were not implemented, taking properly into account all the energy losses the overall 
efficiency would not be much higher, because even the simplest implementation would require a DC/DC converter, whose efficiency is approximately $90 \%$, and some connecting power cables whose impedance usually causes non-negligible power losses.

\section{Acknowledgments}

This work has been carried out under the FEMAG cooperative research project (CRAFT), funded within the $6^{\text {th }}$ EU Framework Programme.

The authors would like to acknowledge the invaluable effort provided by all the staff of Labor s.r.l., the projects' coordinator, as well as the contribution of the SME and RTD performers involved in the project.

\section{References}

[1] Larminie J, Dicks A. Fuel Cell Systems Explained, Second Edition. John Wiley and Sons, Chichester, UK, 2003, pp. 362-367.

[2] Suppes GJ, Lopes S, Chiu CW. Plug-in fuel cell hybrids as transition technology to hydrogen infrastructure. Int J Hydrogen Energy 2004;29(4):369374.

[3] Electricity storage: Ne plus ultra - A new version of an old idea is threatening the battery industry. The Economist Jan $31^{\text {st }} 2008$.

[4] Thounthong P, Raël S, Davat B. Control strategy of fuel cell/supercapacitors hybrid power sources for electric vehicle. J Power Sources 2006;158(1):806-814. [5] Lee HS, Jeong KS, Oh BS. An experimental study of controlling strategies and drive forces for hydrogen fuel cell hybrid vehicles. Int J Hydrogen Energy 2003;28(2):215-222. 
[6] Field Experience Validates Hydrogenics HyPM ${ }^{\circledR}$ Fuel Cell Power Packs for Multi-Shift Lift Truck Operations. Hydrogenics Corporation, white paper, 2006. Available from http://www.salesexpander.com/se/web_folder/30//pdf/field_experience.pdf.

[7] Conte M, Prosini PP, Passerini S. Overview of energy/hydrogen storage: stateof-the-art of the technologies and prospects for nanomaterials. Materials Science and Engineering: B 2004;108(1-2):2-8.

[8] Van Mierlo J, Maggetto G, Lataire Ph. Which energy source for road transport in the future? A comparison of battery, hybrid and fuel cell vehicles. Energy Conversion and Management 2006;47(17):2748-2760.

[9] Fuel Cell Power Systems for Professional Video Camera Applications. Jadoo Power Systems, white paper, 2004. Available from:

http://www.broadcastpapers.com/whitepapers/JadooFuelCellPower.pdf.

[10] Hoogers G. Fuel Cell Technology Handbook. CRC Press LLC, Boca Raton, FL, 2003, p. 277.

[11] Gambini M, Manno M, Vellini M. Metal hydride storage systems: state of the art analysis and integration in FC-based energy systems. In: Proceedings of HYPOTHESIS VII, Merida, Mexico; March 27-30, 2007.

[12] Hoogers G. op. cit. p. 211.

[13] Ahluwalia RK, Wang X, Rousseau A, Kumar R. Fuel economy of hydrogen fuel cell vehicles. J Power Sources 2004;130(1-2):192-201.

[14] Schlapbach L, Züttel A. Hydrogen-storage materials for mobile applications. Nature 2001;414(6861):353-358.

[15] Potera C. Beyond Batteries: Portable Hydrogen Fuel Cells. Environmental Health Perspectives 2007;115(1):A38-A41. 
[16] Kim J, Lee SM, Srinivasan S, Chamberlin CE. Modeling of Proton Exchange

Membrane Fuel Cell Performance with an Empirical Equation. J Electrochem.

Soc. $1995 ; 142(8): 2670-2674$.

[17] Larminie J, Dicks A. op. cit. p. 35.

[18] Hou Y, Zhuang M, Wan G. The analysis for the efficiency properties of the fuel cell engine. Renewable Energy 2007;32(7):1175-1186.

[19] Pei P, Ouyang M, Lu Q, Huang H, Li X. Testing of an automotive fuel cell system. Int J Hydrogen Energy 2004;29(10):1001-1007. 


\section{Figure captions}

Fig. 1. Hydrogen-powered electric wheelchair with the FEMAG module clearly visible

Fig. 2. Electric wheelchair FEMAG module inside view

Fig. 3. FEMAG architecture

Fig. 4. DEA 1.5 Polarization curve

Fig. 5. Stack voltage and power output as functions of current

Fig. 6. Correlation between current drawn by the auxiliaries and net current output

Fig. 7. Fuel cell efficiency

Fig. 8. Base cycle for the experimental tests

Fig. 9. FEMAG control panel with indication of the measured variables

Fig. 10. Test results (power)

Fig. 11. Test results (current)

Fig. 12. Test results (voltage)

Fig. 13. Energy fluxes for a cyclical operation of the FEMAG system

Fig. 14. Power fluxes at time 90 s: the ultracapacitors assist the fuel cell in supplying the required load

Fig. 15. Power fluxes at time $110 \mathrm{~s}$ : the fuel cell recharges the ultracapacitor pack when almost no external load is applied 


\section{Tables}

Table 1

Empirical coefficients in the analytical expression of the polarization curve

\begin{tabular}{ll}
\hline Coefficient & Value \\
\hline$\alpha$ & 0.3629 \\
$i_{0}$ & $6.25710^{-6} \mathrm{~A} \mathrm{~cm}^{-2}$ \\
$r$ & $0.1752 \Omega \mathrm{cm}^{2}$ \\
$m$ & $1.87910^{-4} \mathrm{~V}$ \\
$n$ & $6.887 \mathrm{~cm}^{2} \mathrm{~A}^{-1}$ \\
\hline
\end{tabular}


Table 2

Overall system efficiencies at different working conditions

\begin{tabular}{|c|c|c|c|c|}
\hline $\begin{array}{l}\text { High power } \\
\text { level }[\mathrm{W}]\end{array}$ & $\begin{array}{r}\text { Low power } \\
\text { level [W] }\end{array}$ & $\begin{array}{l}\text { Permanent } \\
\text { duration [s] }\end{array}$ & $\begin{array}{r}\text { Average } \\
\text { power [W] }\end{array}$ & $\begin{array}{r}\text { Overall } \\
\text { efficiency }\end{array}$ \\
\hline 900 & 300 & 20 & 362.5 & 0.3691 \\
\hline 900 & 400 & 20 & 391.0 & 0.3793 \\
\hline 900 & 500 & 20 & 419.4 & 0.3807 \\
\hline 1000 & 300 & 20 & 391.0 & 0.3853 \\
\hline 1000 & 400 & 20 & 419.4 & 0.3730 \\
\hline 1000 & 500 & 20 & 447.9 & 0.3775 \\
\hline 800 & 300 & 30 & 486.8 & 0.3906 \\
\hline 800 & 400 & 30 & 529.6 & 0.3975 \\
\hline 800 & 500 & 30 & 571.5 & 0.3980 \\
\hline 900 & 300 & 30 & 529.2 & 0.3688 \\
\hline 900 & 400 & 30 & 571.5 & 0.3743 \\
\hline 900 & 500 & 30 & 613.9 & 0.3771 \\
\hline 1000 & 300 & 30 & 571.5 & 0.3654 \\
\hline 1000 & 400 & 30 & 613.9 & 0.3711 \\
\hline 1000 & 500 & 30 & 656.2 & 0.3749 \\
\hline
\end{tabular}




\section{Figure 1 \\ down high resolution image \\ Accepted manuscript}

https://doi.org/10.1016/j.ijhydene.2009.01.043
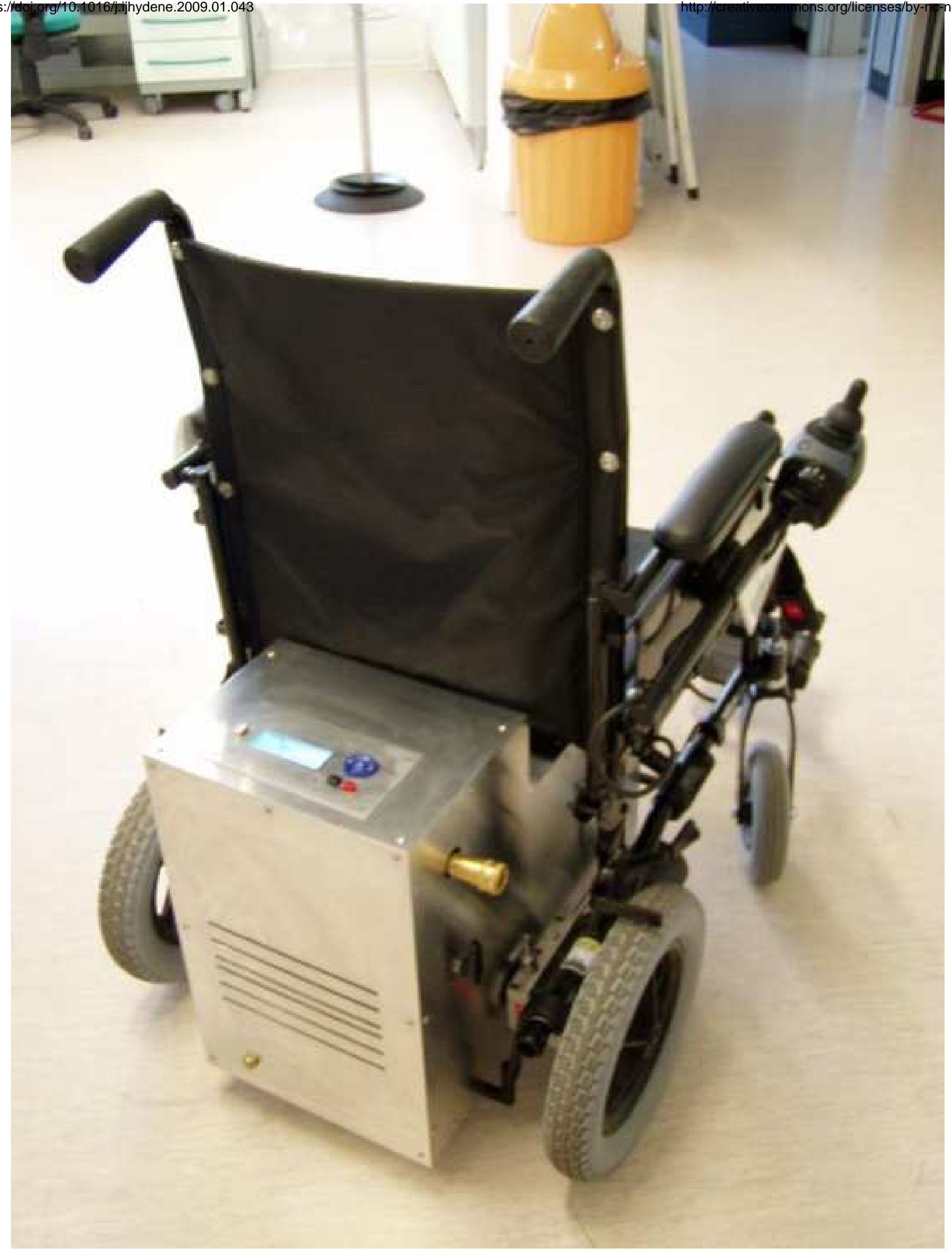

(C) 2009. This manuscript version is made available under the CC-BY-NC-ND 4.0 license.

G.L. Guizzi, M. Manno, M. De Falco, Hybrid fuel cell-based energy system with metal hydride hydrogen storage for small mobile applications, International Journal of Hydrogen Energy 34 (2009) 3112-3124, https://doi.org/10.1016/j.ijhydene.2009.01.043. 
Click here to download high resolution image

Accepted manuscript

https://doi.org/10.1016/j.j.jhydene.2009.01.043

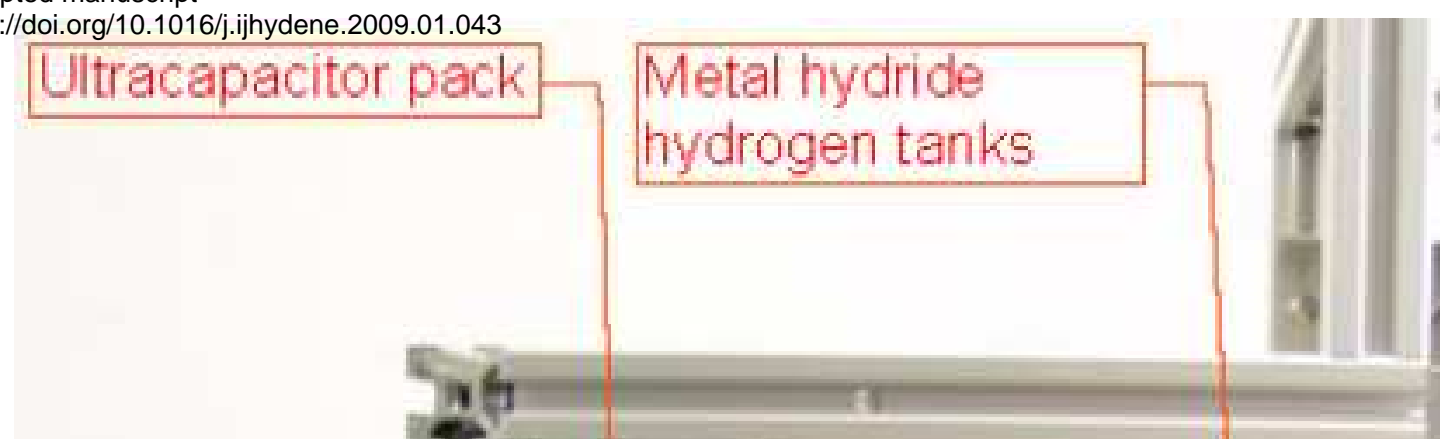

(c) 2009. This manuscript version is made available under the CC-BY-NC-ND 4.0 license.

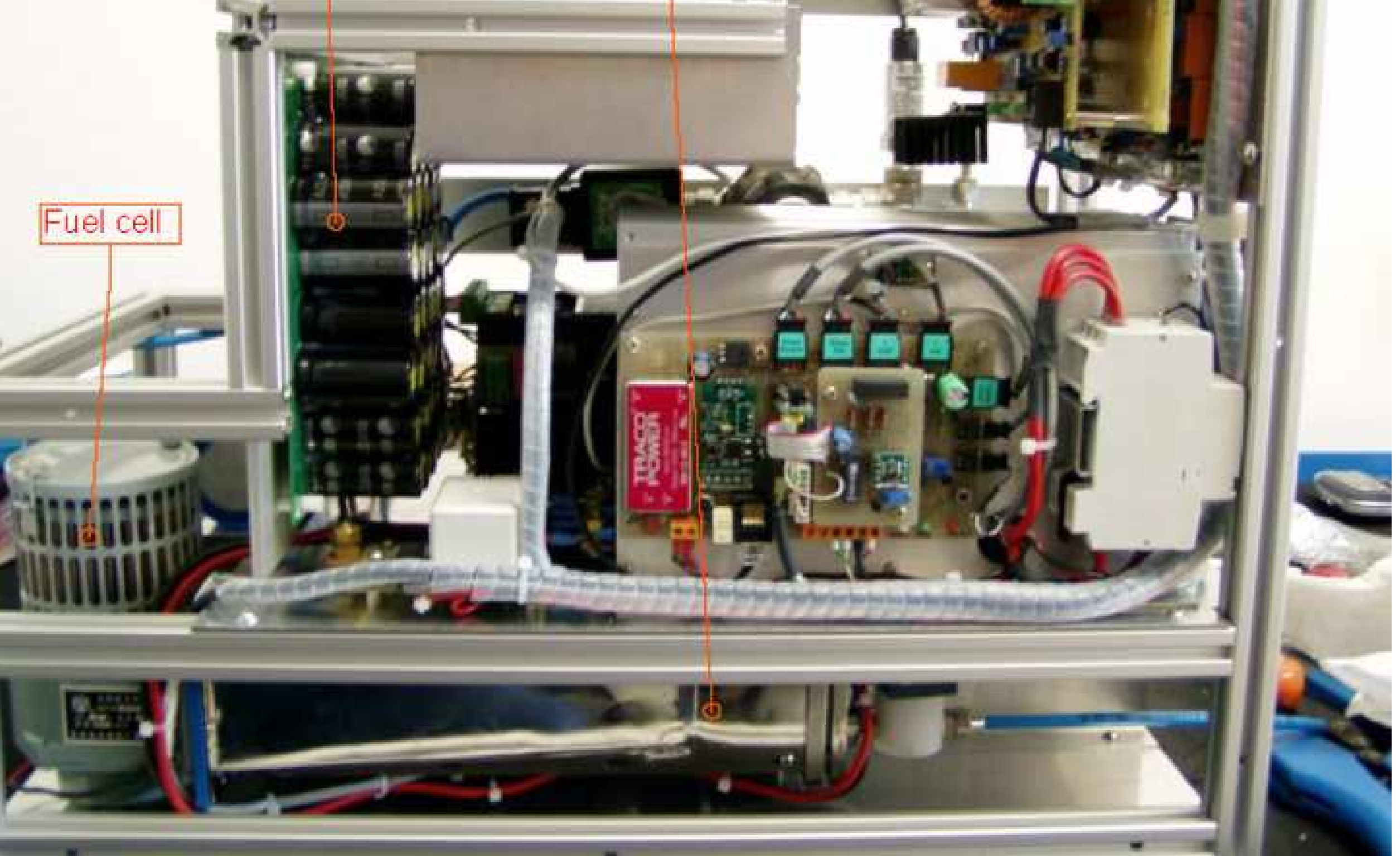

G.L. Guizzi, M. Manno, M. De Falco, Hybrid fuel cell-based energy system with metal hydride hydrogen storage for small mobile applications, International Journal of Hydrogen Energy 34 (2009) 3112-3124, https:// doi.org/10.1016/j.jijhydene.2009.01.043. 


\section{Figure 3}

Accepted manuscript

https://doi.org/10.1016/j.ijhydene.2009.01.043 (c) 2009. This manuscript version is made available under the CC-BY-NC-ND 4.0 license. http://creativecommons.org/licenses/by-nc-nd/4.0

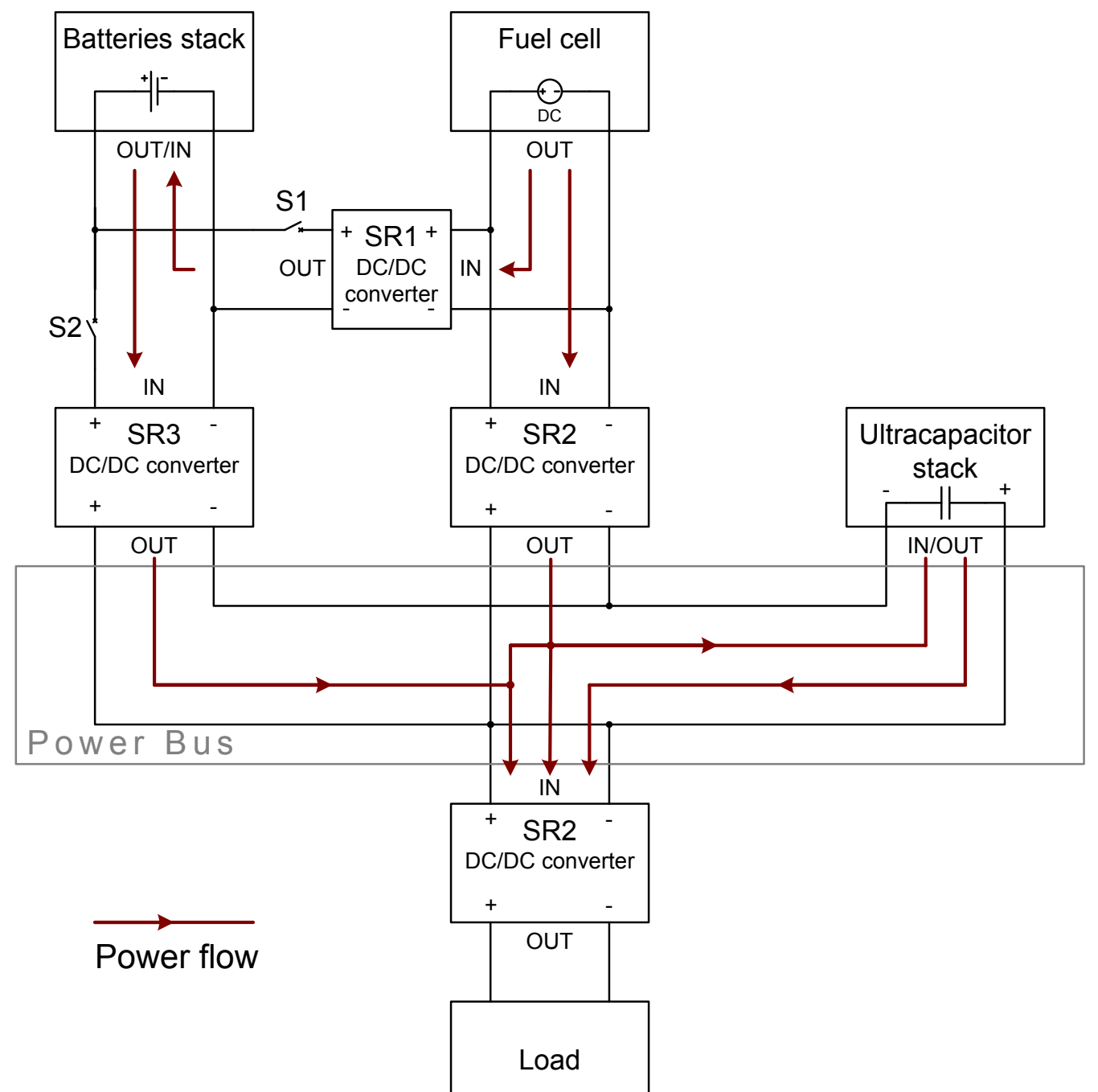

G.L. Guizzi, M. Manno, M. De Falco, Hybrid fuel cell-based energy system with metal hydride hydrogen storage for small mobile applications, International Journal of Hydrogen Energy 34 (2009) 3112-3124, https://doi.org/10.1016/j.ijhydene.2009.01.043. 


\section{Figure 4}

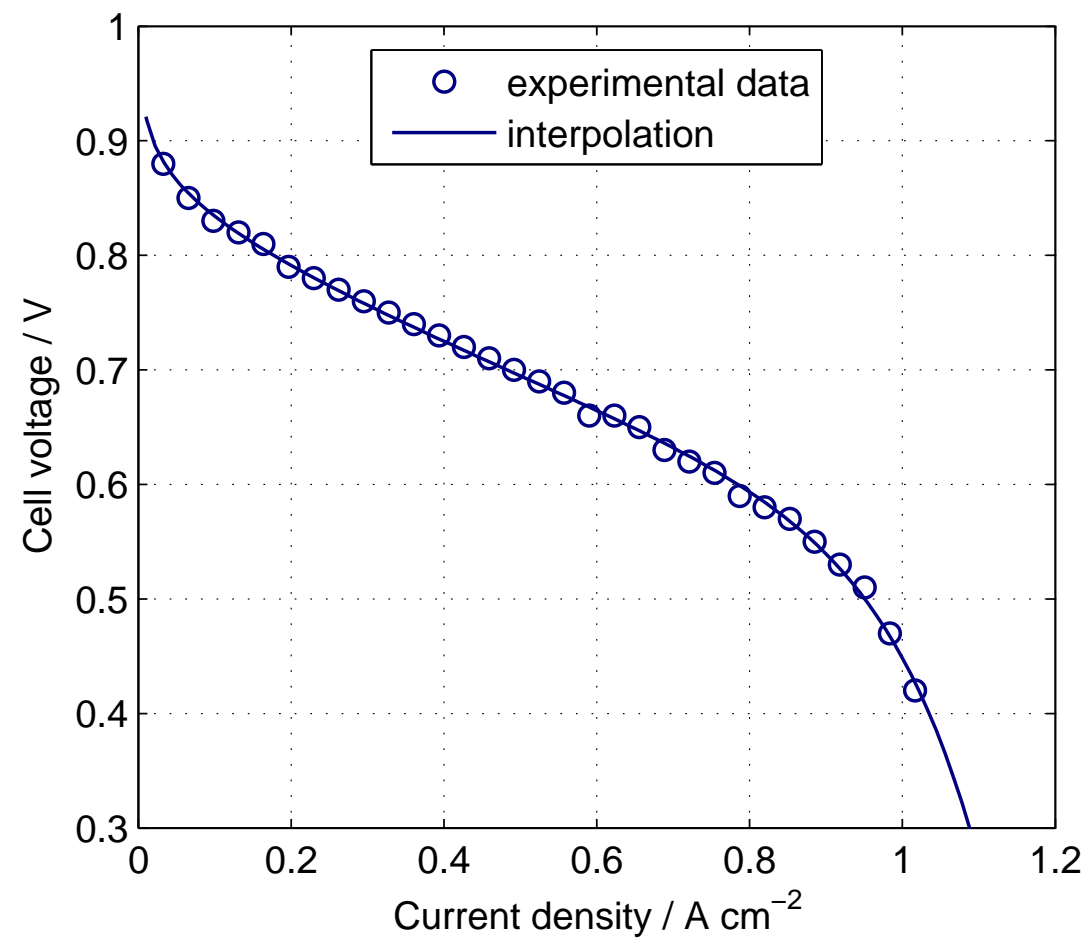

G.L. Guizzi, M. Manno, M. De Falco, Hybrid fuel cell-based energy system with metal hydride hydrogen storage for small mobile applications, International Journal of Hydrogen Energy 34 (2009) 3112-3124, https://doi.org/10.1016/j.jijhydene.2009.01.043. 


\section{Figure 5}

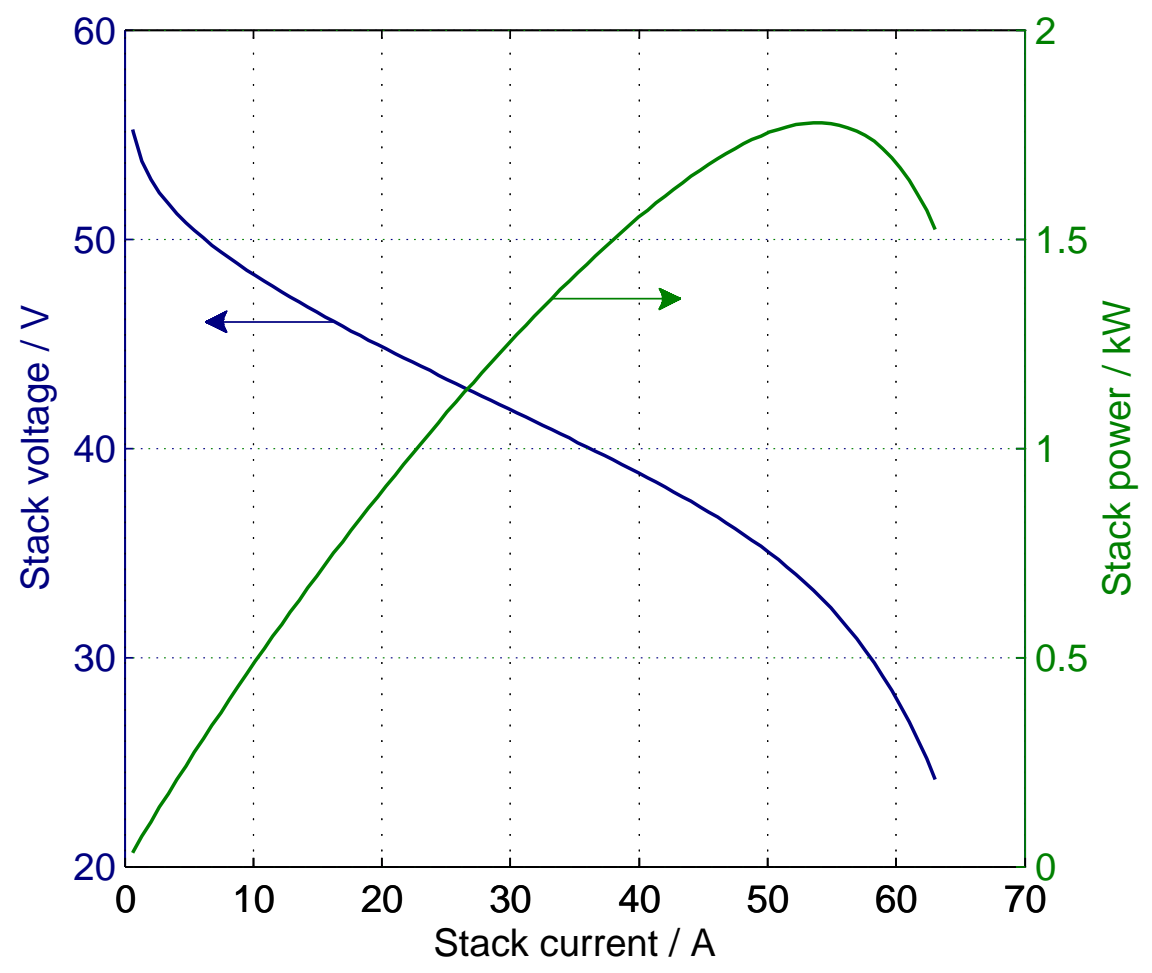

G.L. Guizzi, M. Manno, M. De Falco, Hybrid fuel cell-based energy system with metal hydride hydrogen storage for small mobile applications, International Journal of Hydrogen Energy 34 (2009) 3112-3124, https://doi.org/10.1016/j.jijydene.2009.01.043. 


\section{Figure 6}

Accepted manuscript https://doi.org/10.1016/j.ijhydene.2009.01.043
(C) 2009. This manuscript version is made available under the CC-BY-NC-ND 4.0 license. $\mathrm{http}: / /$ creativecommons.org/licenses/by-nc-nd/4.0

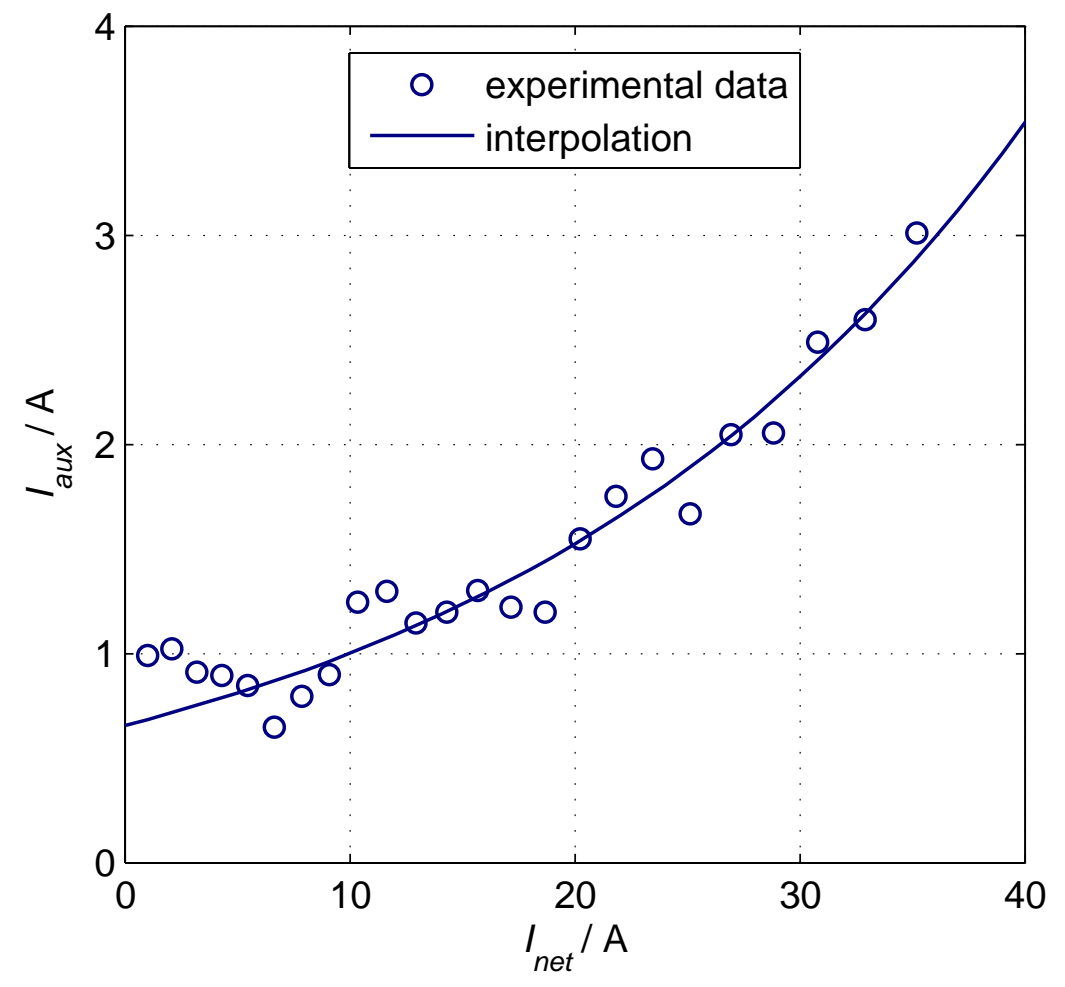

G.L. Guizzi, M. Manno, M. De Falco, Hybrid fuel cell-based energy system with metal hydride hydrogen storage for small mobile applications, International Journal of Hydrogen Energy 34 (2009) 3112-3124, https://doi.org/10.1016/j.jijhydene.2009.01.043. 


\section{Figure 7}

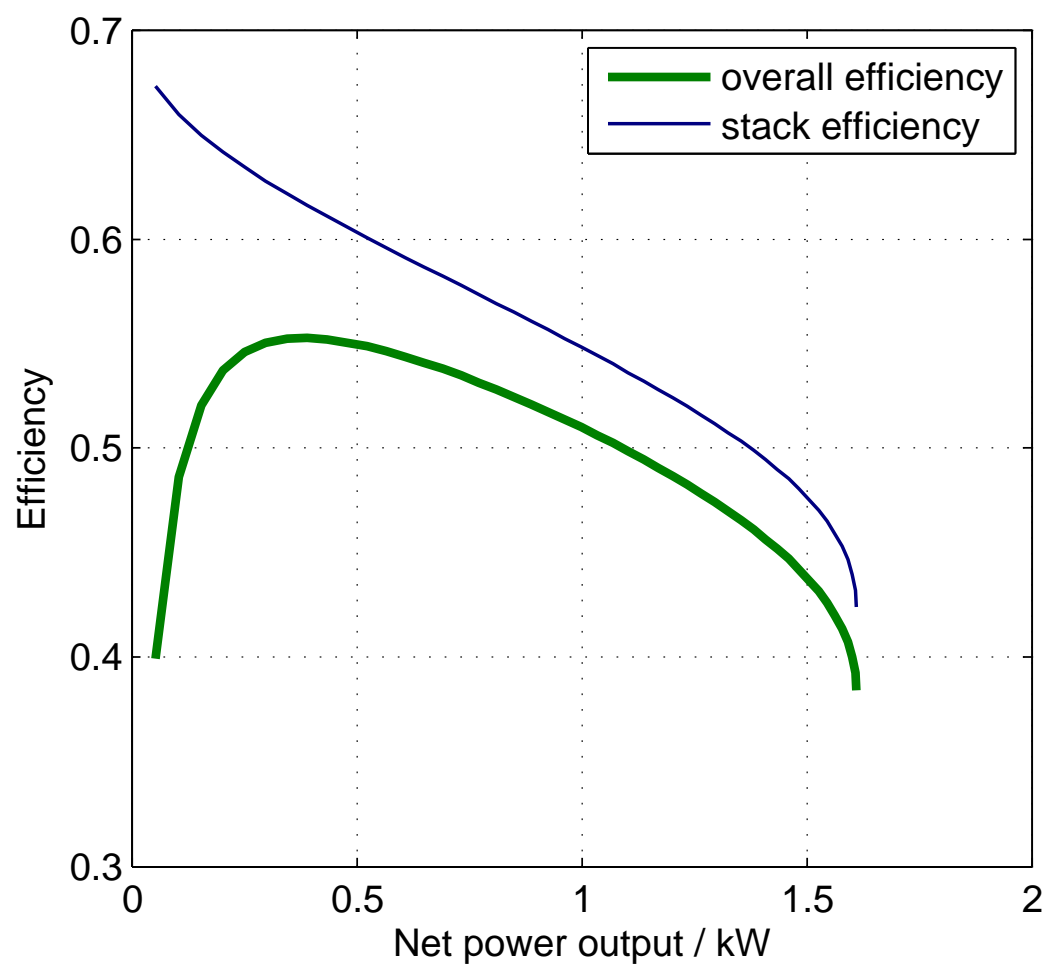

G.L. Guizzi, M. Manno, M. De Falco, Hybrid fuel cell-based energy system with metal hydride hydrogen storage for small mobile applications, International Journal of Hydrogen Energy 34 (2009) 3112-3124, https://doi.org/10.1016/j.ijhydene.2009.01.043. 


\section{Figure 8}

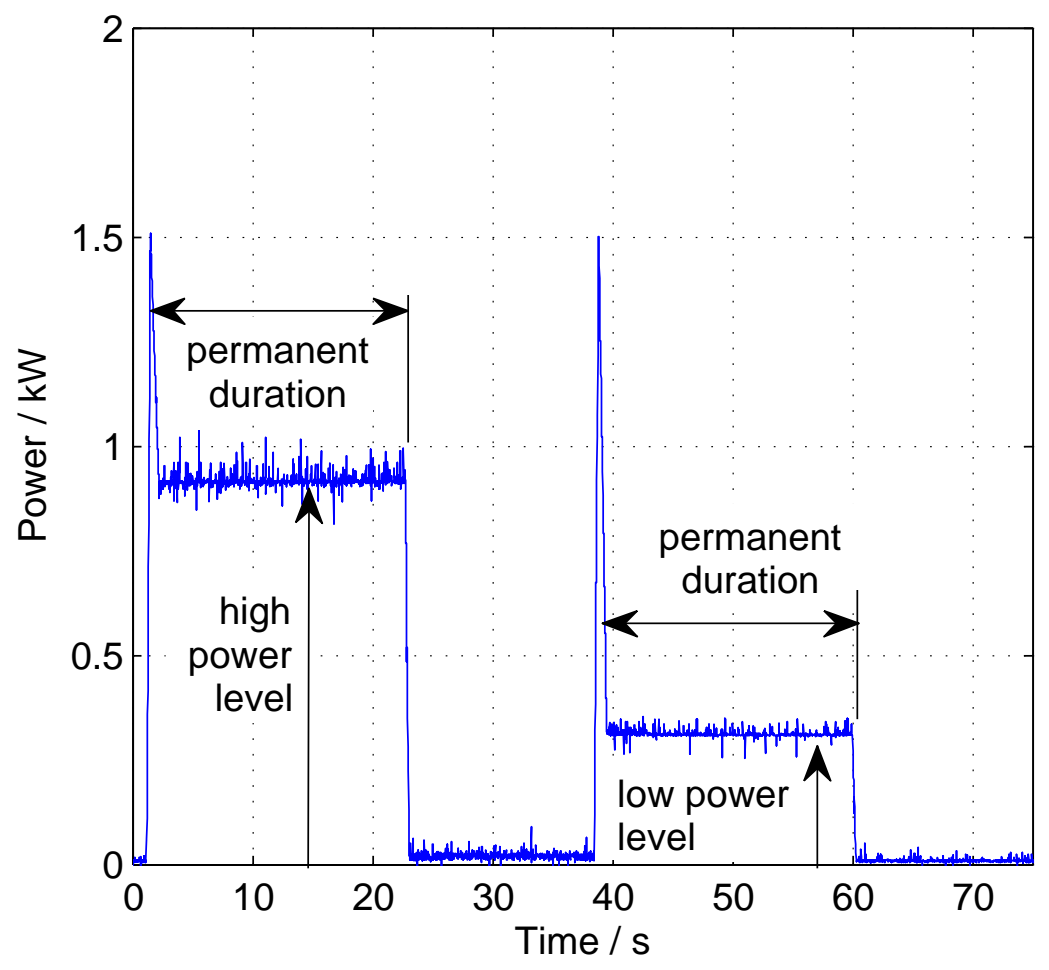

G.L. Guizzi, M. Manno, M. De Falco, Hybrid fuel cell-based energy system with metal hydride hydrogen storage for small mobile applications, International Journal of Hydrogen Energy 34 (2009) 3112-3124, https://doi.org/10.1016/j.jijhydene.2009.01.043. 


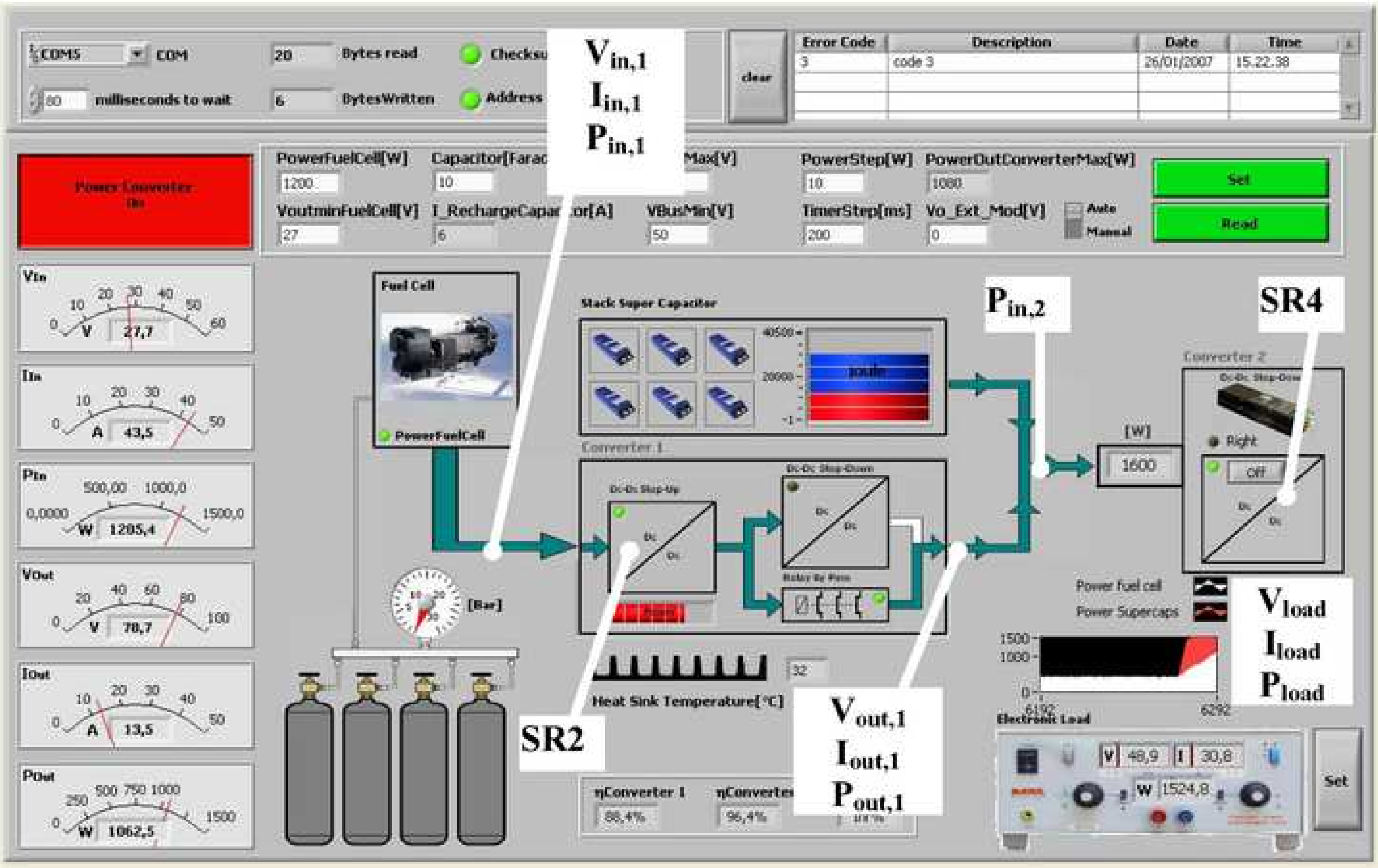

G.L. Guizzi, M. Manno, M. De Falco, Hybrid fuel cell-based energy system with metal hydride hydrogen storage for small mobile applications, International Journal of Hydrogen Energy 34 (2009) 3112-3124, https:// doi.org/10.1016/j.jijhydene.2009.01.043. 


\section{Figure 11}

Accepted manuscript

https://doi.org/10.1016/j.ijhydene.2009.01.043 (c) 2009. This manuscript version is made available under the CC-BY-NC-ND 4.0 license. http://creativecommons.org/licenses/by-nc-nd/4.0
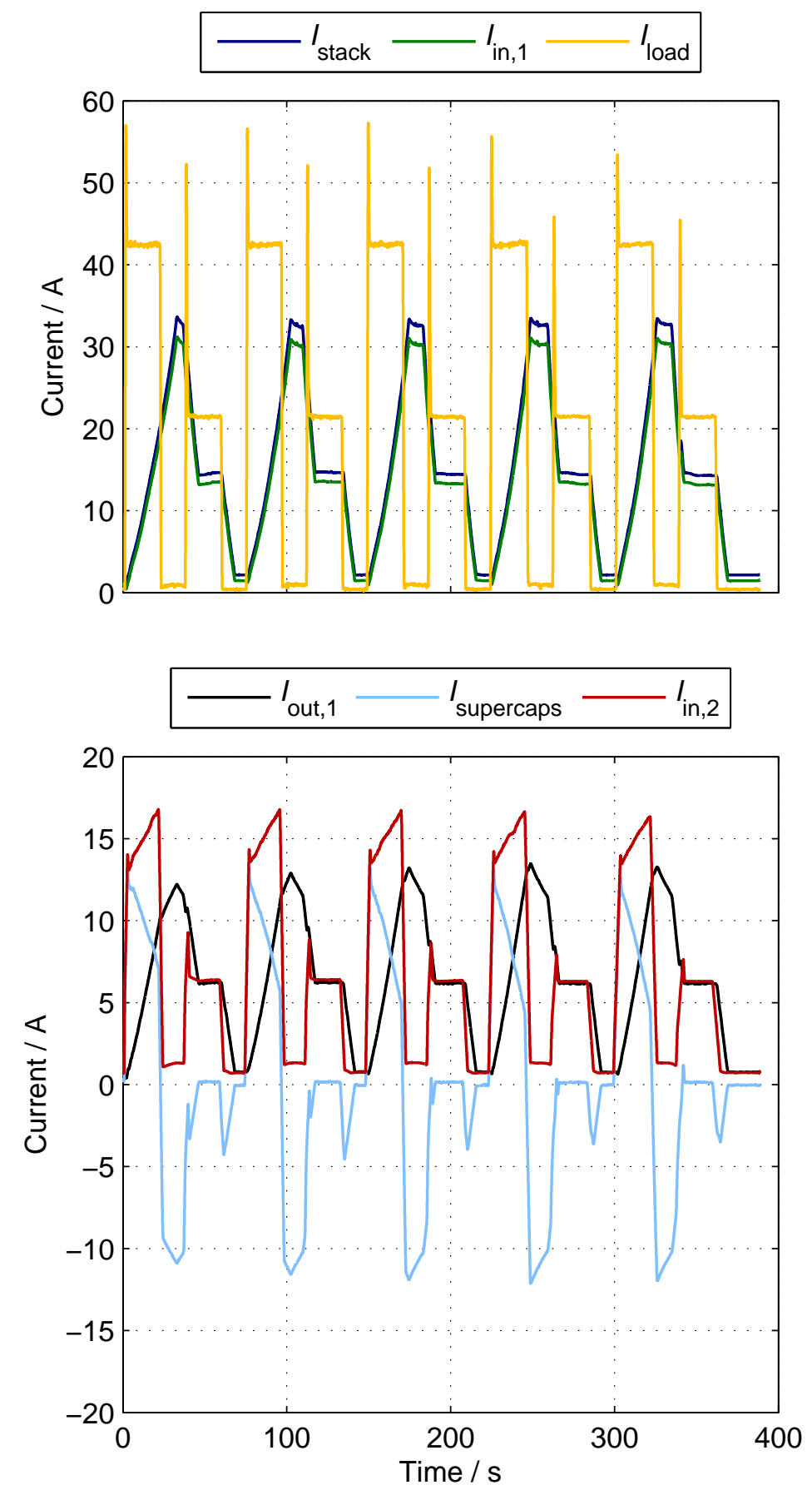

G.L. Guizzi, M. Manno, M. De Falco, Hybrid fuel cell-based energy system with metal hydride hydrogen storage for small mobile applications, International Journal of Hydrogen Energy 34 (2009) 3112-3124, https://doi.org/10.1016/j.jijhydene.2009.01.043. 


\section{Figure 12}

Accepted manuscript

https://doi.org/10.1016/j.ijhydene.2009.01.043 (c) 2009. This manuscript version is made available under the CC-BY-NC-ND 4.0 license. http://creativecommons.org/licenses/by-nc-nd/4.0

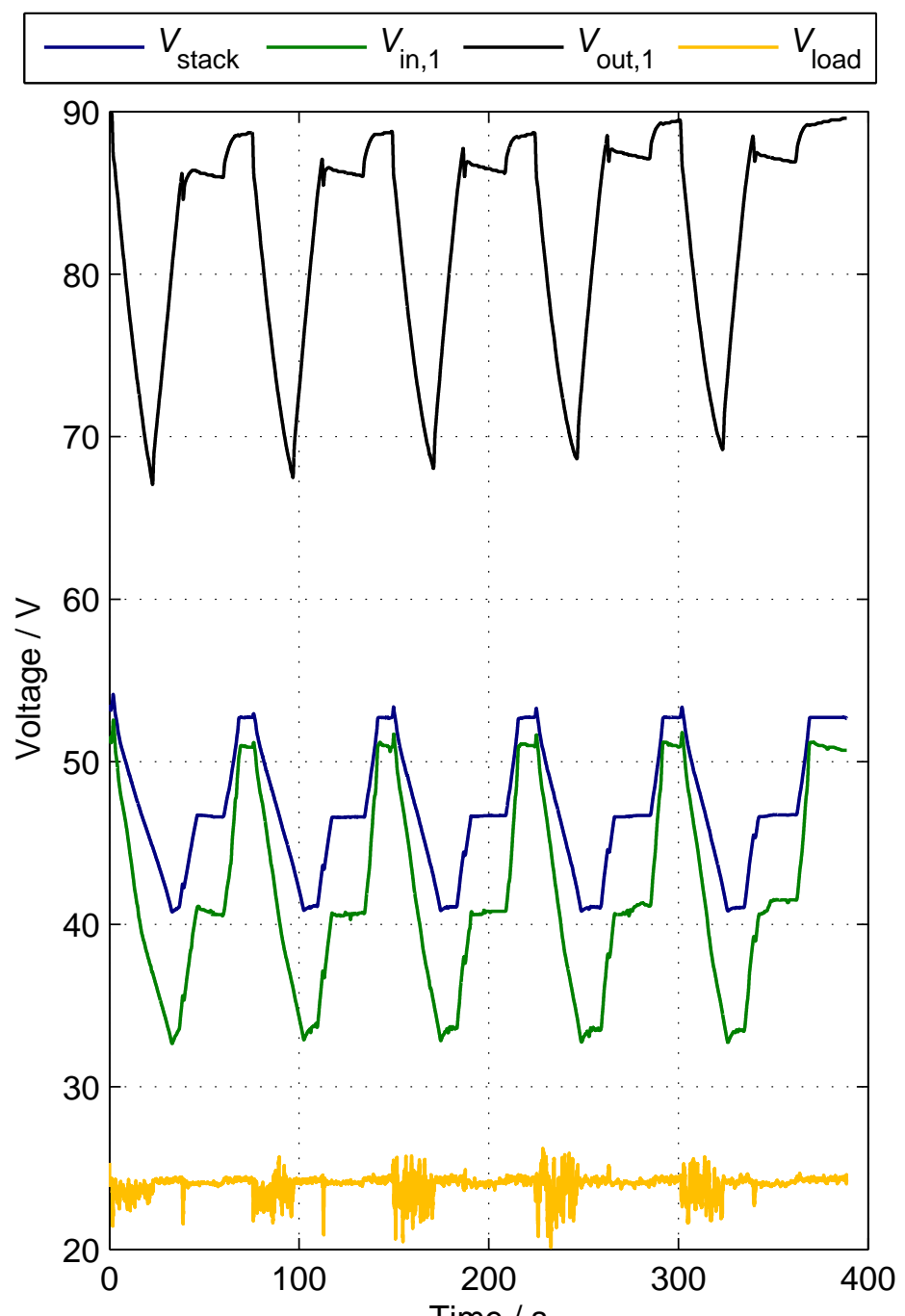

G.L. Guizzi, M. Manno, M. De Falco, Hybrid fuel cell-based energy system with metal hydride hydrogen storage for small mobile applications, International Journal of Hydrogen Energy 34 (2009) 3112-3124, https://doi.org/10.1016/j.jijhydene.2009.01.043. 


\section{Figure 13}

Accepted manuscript

https://doi.org/10.1016/j.ijhydene.2009.01.043 (c) 2009. This manuscript version is made available under the CC-BY-NC-ND 4.0 license. http://creativecommons.org/licenses/by-nc-nd/4.0

\section{FC energy conversion losses}

$43,7 \%$

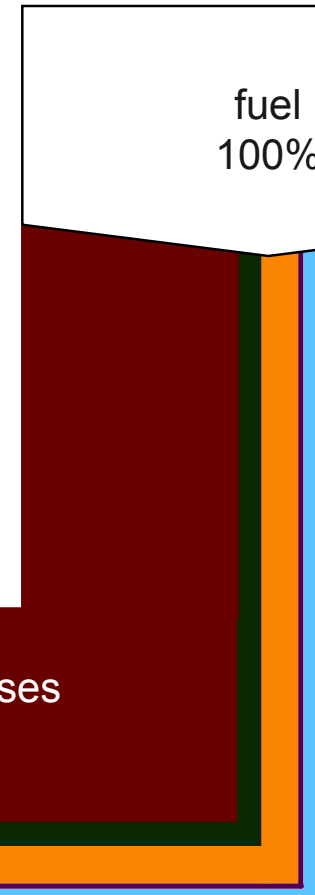

FC auxiliaries 4,9\%

cable losses $7,6 \%$

SR2 conversion losses $1,1 \%$

SR4 conversion losses 4,9\%

G.L. Guizzi, M. Manno, M. De Falco, Hybrid fuel cell-based energy system with nn hal hide hydrogen storage for small mobile applications, International Journal of Hydrogen Energy 34 (2009) 3112-3124, https://doi.org/10.1016/j.ijhydene.2009.01.043. 


\section{Figure 14}

Accepted manuscript https://doi.org/10.1016/j.ijhydene.2009.01.043
(C) 2009. This manuscript version is made available under the CC-BY-NC-ND 4.0 license. $\mathrm{http}: / /$ creativecommons.org/licenses/by-nc-nd/4.0

\section{FC energy conversion losses}

$491 \mathrm{~W}$

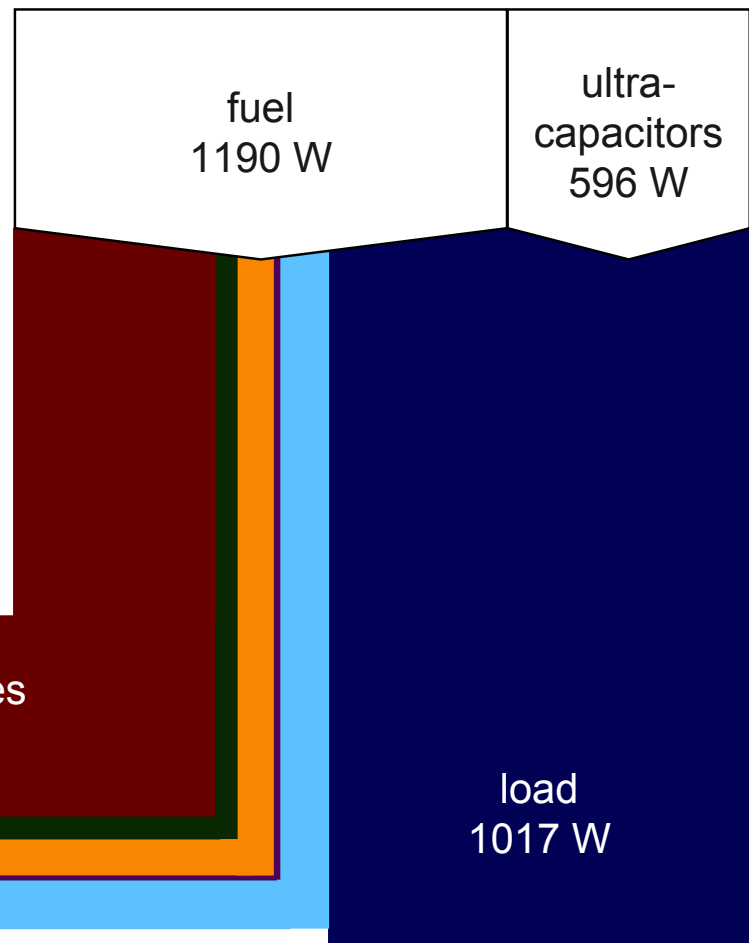

FC auxiliaries $55 \mathrm{~W}$

cable losses $90 \mathrm{~W}$

SR2 conversion losses $13 \mathrm{~W}$

SR4 conversion losses $120 \mathrm{~W}$

G.L. Guizzi, M. Manno, M. De Falco, Hybrid fuel cell-based energy system with metal hyound Hydrogen Energy 34 (2009) 3112-3124, https://doi.org/10.1016/j.ijhydene.2009.01.043. 


\section{Figure 15}

Accepted manuscript https://doi.org/10.1016/j.ijhydene.2009.01.043 (c) 2009. This manuscript version is made available under the CC-BY-NC-ND 4.0 license. http://creativecommons.org/licenses/by-nc-nd/4.0

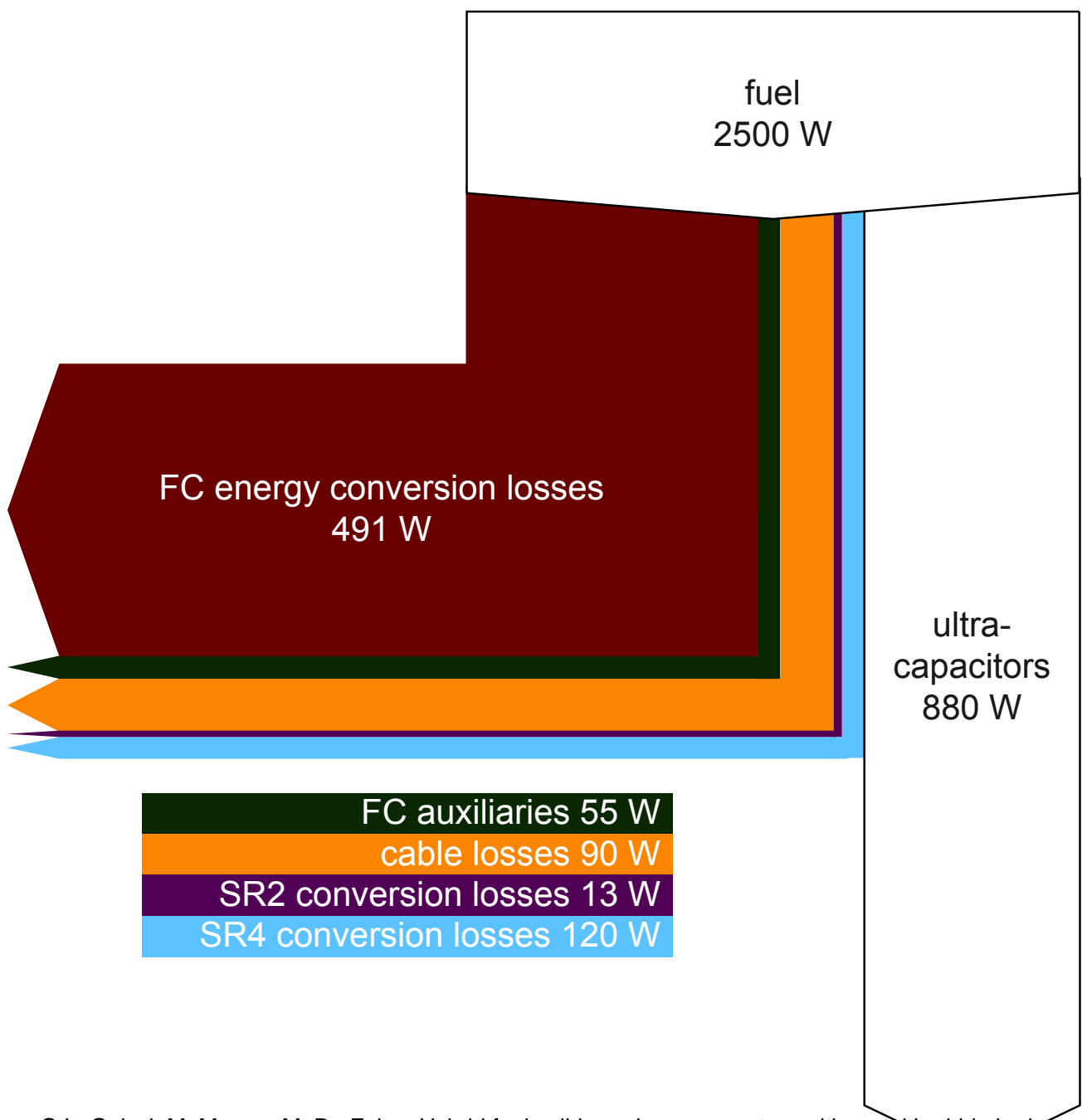

G.L. Guizzi, M. Manno, M. De Falco, Hybrid fuel cell-based energy system with metankydride hydrogen storage for small mobile applications, International Journal of Hydrogen Energy 34 (2009) 3112-3124, https://doi.org/10.1016/j.ijhydene.2009.01.043. 